УДК 355.233.2:796:356.13(043.3)

Олександр Гнидюк, кандидат педагогічних наук Національна академія Державної прикордонної служби України імені Богдана Хмельницького

ORCID ID 0000-0003-3154-1697

DOI: $10.33099 / 2617-1775 / 2021-02 / 51-59$

\title{
ОСОБЛИВОСТІ ФІЗИЧНОЇ ПІДГОТОВКИ ОФІЦЕРІВ У ВІЙСЬКОВИХ ЗАКЛАДАХ ОСВІТИ В КАНАДІ
}

\begin{abstract}
Анотація. $У$ статті представлено результати аналізу особливості фізичної підготовки офіиерів у військових закладах освіти в Канаді. Детально представлено особливості фізичної підготовки на прикладі ї̈ організації в Королівському військовому коледжі Канади. Освітня програма в цъьому коледжі пропонує виняткові можливості для розвитку потенціалу кадетів-спортсменів. Спортивний компонент є одним із чотирьох компонентів підготовки офіџерських кадрів у Королівському військовому коледжі Канади. Програма «Легка атлетика» покликана надати всім майбутнім офічерам можливість брати участь у фізичній діяльності та видах спорту, які вимагають навантаження $з$ метою розвитку їх загальних фізичних можливостей, впевненості в собі та лідерства. Програма фізичної підготовки має на меті поліпшення фізичної підготовленості курсантів; розвиток лідерських можливостей; створення конкурентного середовища; ознайомлення кадетів з різними видами спорту; розвиток командного духу та духу; пропаганда активного та здорового способу життя. Під час навчання кадети проходять випробування фізичної придатності за допомогою фітнес-тесту, який проводиться два рази на рік.Він складається з бігу на 2,4 км на час, максимального числа повторень віджсимань $і$ присідань, стрибків у довжину та бігу на спритність.

Ключові слова: система фізичної підготовки; офіцерські кадри; військові заклади освіти; тенденції професійної підготовки; військовий коледж; збройні сили Канади.
\end{abstract}

Постановка проблеми. Розвиток Державної прикордонної служби України (далі - ДПСУ)в сучасних умовахта діяльність прикордонного відомства відбувається в складній воєнно-політичній ситуації. Вона характеризуються поступовим виконанням зобов'язань України щодо реалізації Угоди про асоціацію з Європейським Союзом у напрямі створення дієвої системи запобігання та протидії різним видам загроз у сфері прикордонної безпеки, а також активною участю військовослужбовців ДПСУ у стримуванні збройної агресії Російської Федерації на території Донецької та Луганської областей, що відбувається на східному кордоні України. В цих умовах особливого значення набуває якість та інтенсивність фізичної підготовки всіх категорій військовослужбовців ДПСУ і, зокрема, офіцерів, оскільки від них в умовах ведення бойових дій вимагається бути витривалими, здатними переносити різнопланові фізичні та психологічні навантаження, адекватно діяти в умовах фізичних перевантажень. 3 метою пошуку ефективних шляхів вирішення завдань щодо підготовки офіцерів ДПСУ, зокрема фізичної підготовки, важливе значення має дослідження організаційно-педагогічних та дидактичних засад фізичної підготовки офіцерів збройних сил та фахівців прикордонних служб у країнах-членах НАТО, зокрема Канади. 
Аналіз останніх досліджень i публікацій. 3 метою узагальнення особливостей фізичної підготовки офіцерських кадрів у військових закладах освіти в Канаді на початку XXI століття здійснено аналітико пошукове дослідження. За його результатами виокремлено праці, у яких розглядаються окремі аспекти фізичної підготовки у країнах НАТО. Йдеться про праці Ю. Бородіна (особливості організації фізичної підготовки у вищих військових навчальних закладах країн НАТО) [1], О. Діденка, С. Шумовецької та О. Луцького (професійна підготовка співробітників прикордонної служби Сполучених Штатів Америки та Свропейських країн) [8], В. Рябчука (міжнародне військово-спортивне співробітництво та фізична підготовка іноземних армій) [4], О. Наговіцина (особливості проведення військової підготовки у країнах НАТО та збройних силах США) [3], І. Скворока (підготовка офіцерів запасу в зарубіжних країнах) [5], А. Стрелецького (система підготовки офіцерських кадрів у США) [6], В. Утенка (різні моделі фізичної підготовки у іноземних арміях) [7] та інших.

Водночас деякі важливі аспекти фізичної підготовки офіцерів у військових закладах освіти в країнах Північної Америки на початку XXI століття, зокрема у Канаді, потребують додаткового узагальнення та аналізу.

Мета статті - дослідити та виокремити особливості та організаційнопедагогічні засади фізичної підготовки офіцерів у військових закладах освіти в Канаді.

Методи дослідження. Для досягнення мети дослідження використано методи аналізу, узагальнення, порівняння та систематизації. У якості джерельної бази використано інформацію, що міститься на офіційних сайтах закладів військової освіти Канади, зокрема Королівського військового коледжу Сен-Жан (RoyalMilitaryCollegeSaint-Jean, RMCSJ) [14];Академій Роберта Ленда (Robert Land Academy, RLA) [13];Командно-штабного коледжу канадської армії (Canadian Army Command and Staff College, CACSC) [9]; Королівського військового коледжу Канади (Royal Military College of Canada, RMCC) [15]; Коледжу збройних сил Канади (Canadian Forces College, CFC) [10]; Академії Рендольфа-Мейкона (Randolph-MaconAcademy, R-MA) [11].

Виклад основного матеріалу.Результати узагальнення інформації з різних офіційних джерел дозволяють зробити висновок, що Канадські збройні сили (CF - Canadian Forces)складаються iз сухопутних, військово-морських, військово-повітряних, комунікаційних та тренувальних підрозділів, частин i з'єднань. У Канадських збройних силах проходять службу рядові та офіцери. На структурному рівні Канадські збройні сили поділяються на п'ять видів і складаються з регулярних сил, резервних сил, додаткового резерву, командного складу інструкторів військових училищ та канадських рейнджерів. Канадські рейнджери - це компонент збройних сил Канади, що нараховує близько 5000 чоловік, який забезпечує обмежену військову присутність у мало населених північних, прибережних та ізольованих районах Канади. У цих районах (Північно-західні території, Юкон, Нунавут) досить складно утримувати боєздатні армійські підрозділи, до це є економічно та практично невигідним [2].

Канадські збройні сили будуються на професійній основі. Вони розміщені 
на території Канади, а також в країнах Європи, оскільки Канада є членом HATO 34 квітня 1949 року. Їхнім головним завданням $є$ захист суверенітету та безпеки Канади. Канада та США $є$ партнерами у рамках Командування аерокосмічної оборони Північної Америки (англ. North American Aerospace Defense Command, NORAD). Незважаючи на те, що збройні сили Канади $\epsilon$ досить нечисленними (нараховують близько 68000 військовослужбовців, понад 25000 військовослужбовців запасу, близько 24000 осіб неактивного запасу (цивільних фахівців) та до 5000 Канадських рейнджерів), вони довели свою ефективність. Офіцери сухопутних, військово-морських та військовоповітряних сил готуються у Школі управління та у Королівському військовому коледжі Канади (Онтаріо). Після закінчення навчання вони розподіляються для подальшої служби. Канадські збройні сили будуються на професійній основі та дають можливість для кар'єрного зростання, пропонуючи близько 100 різних військових професій та спеціальностей.

Підготовку офіцерів для збройних сил Канади здійснюють такі заклади:

Королівський військовий коледж Сен-Жан (RoyalMilitaryCollegeSaint-Jean, RMCSJ) [14];

Академія Роберта Ленда (Robert Land Academy, RLA) [13];

Командно-штабний коледж канадської армії (Canadian Army Command and Staff College, CACSC) [9];

Королівський військовий коледж Канади (Royal Military College of Canada, RMCC) [15];

Коледж збройних сил Канади (Canadian Forces College, CFC) [10];

Академія Рендольфа-Мейкона (Randolph-MaconAcademy, R-MA) [11]

Результати узагальнення інформації, розміщеної на офіційних сайтах цих військових закладів освіти дозволяє зробити висновок, що система фізичної підготовки майбутніх офіцерських кадрів $є$ стандартною, про що свідчить порівняння тестів для вступників, вимоги до рівня фізичної підготовки офіцерського складу, а також тести фізичної підготовки, які час від часу мають здавати офіцери збройних сил Канади. 3 огляду на це розглянемо особливості фізичної підготовки на прикладі іiі організації в Королівському військовому коледжі Канади (Royal Military College of Canada, RMCC) [15].

Спортивний компонент $\epsilon$ одним із чотирьох компонентів підготовки офіцерських кадрів у Королівському військовому коледжі Канади. Програма «Легка атлетика» покликана надати всім майбутнім офіцерам можливість брати участь у фізичній діяльності та видах спорту, які вимагають навантаження 3 метою розвитку їх загальних фізичних можливостей, впевненості в собі та лідерства.

Освітня програма в Королівському військовому коледжі Канади пропонує виняткові можливості для розвитку потенціалу кадетів-спортсменів. Таких в навчальному закладі близько $20 \%$, що забезпечує функціонування 7 спортивних команд 3 чоловічого та жіночого фехтування, хокею, регбі, чоловічого і жіночого футболу, чоловічого і жіночого волейболу [15].

Контактні види спорту, за баченням керівництва Королівського військового коледжу Канади, призначені для розвитку сміливості та 
агресивності. Командні види спорту розвивають самопожертву та дух духу. Індивідуальні види спорту розширюють впевненість, врівноваженість і самовпевненість людини. А у комплексі всі види спорту розвивають самодисципліну та здатність швидко й точно реагувати на різні обставини та екстремальні умови служби, зберігаючи контроль і присутність духу. Тому програма фізичної підготовки є надзвичайно важливою для майбутніх офіцерів щодо ефективної служби в якості офіцерів Канадських військ (CF) [15].

Програма фізичної підготовки має на меті поліпшення фізичної підготовленості курсантів; розвиток лідерських можливостей; створення конкурентного середовища; ознайомлення кадетів з різними видами спорту; розвиток командного духу та духу; пропаганда активного та здорового способу життя.

Програма забезпечує можливості кожному кадету брати участь у різноманітних командних видах спорту, щоб практикувати та вдосконалювати спортивні навички. Програма передбачає проведення спортивних змагань на рівні коледжу восени та взимку у вівторок та четвер увечері; спортивні дні курсу, які проводяться в суботу або неділю із залученням усіх кадетів курсу (зазвичай у вересні та лютому).

Крім цього кожен кадет повинен успішно пройти Force-тест (відповідність вимогам служби в збройних силах Канади). Force-тест передбачає виконання серії з чотирьох завдань, призначених для вимірювання придатності до служби, який відображає стандарт мінімальної фізичної готовності військовослужбовця у сфері оборони.

Також під час навчання кадети проходять випробування фізичної придатності за допомогою фітнес-тесту - Physical performance test (PPT), який проводиться два рази на рік. Він складається з бігу на 2,4 км на час, максимального числа повторень віджимань і присідань, стрибків у довжину та бігу на спритність. Програма підготовки до виконання цього тесту представлена на сайті навчального закладу.

Відповідно до програми фізичної підготовки кадети два рази на рік проходять фізичне оцінювання, максимально можна набрати 500 балів, при цьому кожен компонент (біг на 2,4 км - аеробний компонент; віджимання компонент на перевірку витривалості м'язів верхньої частини тіла; Agility Run компонент швидкості; присідання - компонент на перевірку витривалості м'язів середньої частини тіла; стрибки в довжину стоячи - компонент для перевірки сили ніг) оцінюється максимум 100 балами. Для успішного виконання тесту РРТ необхідно набрати мінімум 250 балів. П'ять компонентів фізичної підготовки оцінюються за допомогою різних елементів тестування: біг на 2,4 км, віджимання, біг на спритність, присідання та стрибки в довжину 3 місця [12].

Біг на 2,4 км передбачає подолання трьох кіл по 800 метрів за найшвидший можливий час. Мінімальні норми для кадетів Королівського військового коледжу: чоловіки - 10 хв 34 с, жінки - 12 хв 12 с.

Щодо віджимання, то під час тесту кадети повинні виконати максимальне число повторень. Мінімальні стандарти для чоловіків - 28 повторень, для 
жінок - 14 повторень.

Біг 3 перешкодами (agility run) передбачає 6 циклів по 9 м 3 подоланням чотирьох перешкод (стільців), не торкаючись жодного з них. Дозволено дві спроби, під час виконання яких визначається найкращий результат. Мінімальні стандарти для кадетів Королівського військового коледжу: чоловіки 17,8 секунди, жінки - 19,4 секунди.

Тест на присідання передбачає виконання максимальної кількості повторень впродовж 2-х хвилин відповідно до протоколу канадських військ. Мінімальні стандарти: чоловіки - 35 повторень, жінки - 35 повторень.

Тест на стрибки в довжину передбачає дві спроби, визначається найкращий результат. Мінімальні стандарти: чоловіки - 195 см, жінки - 146 см [12].

Оцінка сили (FORCE Evaluation) складається 3 чотирьох компонентів тесту, кожен 3 яких призначений для вимірювання різних фізичних можливостей:

1) Підйом мішків 3 піском - 30 послідовних підйомів мішка 3 піском вагою 20 кг на висоту 91,5 см, чергуючи лівий i правий мішки 3 піском, які розташовані один від одного на відстані 1,25 м. Норматив - 3 хв 30 с.

2) Човниковий біг з вантажем:

Треба подолати десять відрізків (шатлів) (1 відрізок - 20 м в одну сторону, 20 м - в іншу) із 20-кілограмовим мішком 3 піском та без вантажу, загалом 400 м. Стандарт: 5 хв 21 с.

3) Спритність: 3 положення лежачи потрібно виконати два човникових спринту ( 1 відрізок $=20$ м в одну сторону, 20 м - в іншу), при цьому кожні 10 потрібно зайняти положення «лежачи». Загальна відстань 80 м. Стандарт: $51 \mathrm{c}$.

4) Перетягування мішка 3 піском. Потрібно перенести по одному мішку 3 піском вагою 20 кг на піддон, а потім тягнути чотири мішки по підлозі на відстань не менше 20 м без зупинки. Стандарт: виконати без зупинки.

Якщо учасник не відповідає мінімальним стандартам фізичної підготовки, то можна спробувати повторне тестування через три місяці [12].

\section{Висновки та перспективи подальших досліджень.}

Отже, у військових коледжах Канади фізична підготовка та спорт $є$ обов'язковими елементами освітнього процесу. Мета та завдання фізичного виховання кадетів можуть мати різне формулювання та зміст, проте серед загальних завдань фізичного виховання майбутніх офіцерів $\epsilon$ розвиток фізичних якостей та оволодіння руховими навичками; формування морально-психічної стійкості до впливу екстремальних умов бойової обстановки; формування здатності діяти в екстремальних умовах службово-бойової діяльності; виховання впевненості; забезпечення згуртованості підрозділів; формування потреби у регулярних заняттях фізичними вправами та спортом; формування потреби здорового способу життя.

Якість фізичної підготовки у військових коледжах Канади забезпечується наявністю кваліфікованих фахівців фізичної підготовки та спорту; високим рівнем фізичної підготовленості абітурієнтів під час вступу до військового 
закладу освіти; значним обсягом часу в бюджеті освітньої програми на фізичну підготовку та спорт; сучасною спортивною базою військових закладів освіти; комплексом заходів щодо формування мотивації до занять фізичними вправами та спортом.

Обов'язковим елементом фізичної підготовки $є$ випробування за тестами, що визначають придатність до подальшого навчання у військових закладах освіти та служби в збройних силах. Тестами перевіряються витривалість, швидкість, спритність та сила. Перевірка фізичної підготовленості військовослужбовців відбувається, як правило, не рідше одного-двох разів на рік. При цьому ведеться облік в індивідуальній карті фізичного профілю, де відображаються показники військово-прикладної, спеціальної фізичної, а також спортивної підготовленості та рухової активності. Такий облік показників фізичного стану та спортивної активності дозволяє створити об'єктивну картину індивідуальної траєкторії фізичного розвитку кожного кадета.

\section{ЛІТЕРАТУРА}

1. Бородин Ю. А. Особенности организации физической подготовки в высших военных учебных заведениях стран НАТО. Pedagogics, psychology, medical-biological problems of physical training and sports. 2007. №3. URL: https://cyberleninka.ru/article/n/osobennostiorganizatsii-fizicheskoy-podgotovki-v-vysshih-voennyh-uchebnyh-zavedeniyah-stran-nato (дата звернення: 04.11.2021).

2. Все о Канаде: вооруженные силы Канады. URL: https://immigratecan.ca/all-aboutcanada/voorujennie-sili-canadi/ (дата звернення: 01.11.2021)

3. Наговіцин О. П. Особливості проведення військової підготовки у країнах НАТО та збройних силах США. Сучасні тенденції та перспективи розвитку фізичної підготовки $i$ спорту у Збройних Силах України, правоохоронних органах, рятувальних та інших спеиіальних служб на иляху євроатлантичної інтеграції України: матеріали III Міжнародної науковопрактичної конференції (Київ, 21-22 листопада 2019 р.) Національний університет оборони України імені Івана Черняховського. Київ : НУОУ, 2019. 416 с.

4. Рябчук В. В. Международное военно-спортивное сотрудничество и физическая підготовка иностранных армий: Монография. Санкт-Петербург, МО РФ, 2011. 188 с.

5. Скворок I. М. Підготовка офіцерів запасу в зарубіжних країнах. Військова освіта. 2013. № 1. C. 207-216. URL: http://nbuv.gov.ua/j-pdf/vios_2013_1_26.pdf.

6. Стрелецкий А. Система підготовки офицерских кадров в США. Зарубежное военное обозрение. 2006. № 11. С. 20-27.

7. Утенко В. Н. Различные модели физической подготовки в иностранных армиях. Тез. докл. итог. науч. конф. института за 1999 год., Санкт-Петербург: ВИФК, 2000, С. $137-$ 139.

8. Шумовецька С., Діденко О., Луцький О. Професійна підготовка співробітників прикордонної служби Сполучених Штатів Америки та Європейських країн. Збірник наукових праиь Наиіональної академії Державної прикордонної служби Украӥни. Серія: педагогічні науки, 2021. 25(2), с. 207-224. URL: https://doi.org/10.32453/pedzbirnyk.v25i2.792
9.
Canadian
Army
Command
and
Staff
College.
URL:

https://www.canada.ca/en/department-national-defence/services/benefits-military/educationtraining/establishments/command-staff-college.html(дата звернення: 03.11.2021)

10. Canadian Forces College. URL: https://www.cfc.forces.gc.ca/221-eng.html(дата звернення: 04.11.2021)

11. Randolph-MaconAcademy. URL: https://rma.edu/(дата звернення: 03.11.2021)

12. RMC Physical Performance Test - Joining Instructions. Royal Military College of Canada. URL: https://www.rmc-cmr.ca/en/athletic-department/physical-fitness-guide (дата 
звернення: 01.11.2021)

05.11.2021)

13. Robert Land Academy. URL: https://robertlandacademy.com/(дата звернення:

14. Royal Military College Saint-Jean. URL: cmrsj-rmcsj.forces.gc.ca (дата звернення: 02.11.2021)

15. Royal Military College of Canada. URL: www.rmcc.forces.gc.са(дата звернення: 04.11.2021)

\section{REFERENCES}

1. BorodinYu. A. Osobennosti organizatsii fizicheskoy podgotovki v vyisshih voennyih uchebnyih zavedeniyah stran NATO [Peculiarities of the organization of physical training in higher military educational institutions of NATO countries.]. Pedagogics, psychology, medical-biological problems of physical training and sports. 2007. \#3. URL: https://cyberleninka.ru/article/n/osobennosti-organizatsii-fizicheskoy-podgotovki-v-vysshihvoennyh-uchebnyh-zavedeniyah-stran-nato (data zvernennya: 01.11.2021) [in Russian].

2. Все о Канаде: вооруженные силы Канады [Everything about Canada: Canadian Armed Forces]. URL: https://immigratecan.ca/all-about-canada/voorujennie-sili-canadi/ (data zvernennya: 01.11.2021)

3. Nahovitsyn O. P. Osoblyvosti provedennia viiskovoi pidhotovky u krainakh NATO th zbroinykh sylakh SShA [Peculiarities of military training in NATO countries and the U.S. Armed Forces]. Suchasni tendentsii th perspektyvy rozvytku fizychnoi pidhotovky i sportu u Zbroinykh Sylakh Ukrainy, pravookhoronnykh orhanakh, riatuvalnykh th inshykh spetsialnykh sluzhb na shliakhu yevroatlantychnoi intehratsii Ukrainy: materialy III Mizhnarodnoi naukovo-praktychnoi konferentsii (Kyiv, 21-22 lystopada 2019 r.) Natsionalnyi universytet oborony Ukrainy imeni Ivana Cherniakhovskoho. Kyiv : NUOU, 2019. 416 s.[in Ukrainian]

4. Ryabchuk V. V. Mezhdunarodnoe voenno-sportivnoe sotrudnichestvo i fizicheskaya podgotovka inostrannyih armiy: Monografiya [International Military Sports Cooperation and Physical Training of Foreign Armies: A Monograph.]. Sankt-Peterburg, MO RF, 2011. 188 s.[in Russian]

5. Skvorok I. M. Pidhotovka ofitseriv zapasu v zarubizhnykh krainakh [Training of reserve officers in foreign countries]. Viiskova osvita. 2013. № 1. S. 207-216. URL: http://nbuv.gov.ua/jpdf/vios_2013_1_26.pdf. [in Ukrainian]

6. Streletskiy A. Sistema podgotovki ofitserskih kadrov v SShA [Officer Training System in the United States]. Zarubezhnoe voennoe obozrenie. 2006. № 11. S. 20-27. [in Russian]

7. Utenko V. N. Razlichnyie modeli fizicheskoy podgotovki $\mathrm{v}$ inostrannyih armiyah [Different models of physical training in foreign armies] // Tez. dokl. itog. nauch. konf. Institute za 1999 god., Sankt-Peterburg: VIFK, 2000, S. 137-139. [in Russian]

8. Shumovetska S., Didenko O., Lutskyi O. Profesiina pidhotovka spivrobitnykiv prykordonnoi sluzhby Spoluchenykh Shtativ Ameryky th Yevropeiskykh krain [Professional training for U.S. and European border officials.]. Zbirnyk naukovykh prats Natsionalnoi akademii Derzhavnoi prykordonnoi sluzhby Ukrainy. Seriia: pedahohichni nauky, 2021. 25(2), s. 207-224. URL: https://doi.org/10.32453/pedzbirnyk.v25i2.792 [in Ukrainian]

9. Canadian Army Command and Staff College. URL: https://www.canada.ca/en/departmentnational-defence/services/benefits-military/education-training/establishments/command-staffcollege.html(data zvernennya: 03.11.2021)

10. Canadian Forces College. URL: https://www.cfc.forces.gc.ca/221-eng.html(data zvernennya: 04.11.2021)

11. Randolph-MaconAcademy. URL: https://rma.edu/( data zvernennya: 03.11.2021)

12. RMC Physical Performance Test - Joining Instructions. Royal Military College of Canada. URL: https://www.rmc-cmr.ca/en/athletic-department/physical-fitness-guide (data zvernennya: 01.11.2021)

13. Robert Land Academy. URL: https://robertlandacademy.com/(data zvernennya: 05.11.2021) 
14. Royal Military College Saint-Jean. URL: cmrsj-rmcsj.forces.gc.ca (data zvernennya: 02.11.2021) 15. Royal Military College of Canada. URL: www.rmcc.forces.gc.ca(data zvernennya: 04.11.2021)

\title{
РЕЗЮМЕ
}

\author{
Александр Гныдюк, \\ кандидат педагогических наук \\ Национальная академия Государственной \\ Пограничной службы Украины \\ имени Богдана Хмельницкого
}

\section{Особенности физической подготовки офицеров в военных учебных заведениях в Канаде}

В статье представлены результаты анализа особенностей физической подготовки офицеров в военных учебных заведениях в Канаде. Подробно представлены особенности физической подготовки на примере ее организачии в Королевском военном колледже Канады. Образовательная программа в этом колледже предлагает исключительные возможности развития потенциала кадетов-спортсменов. Спортивный компонент - один из четырех компонентов подготовки офицерских кадров в Королевском военном колледже Канады. Программа «Легкая атлетика» призвана предоставить всем будущим офицерам возможность участвовать в физической деятельности и видах спорта, требующих нагрузки с иелью развития их общих возможностей, уверенности в себе и лидерства. Программа физической подготовки преследует иель улучшения физической подготовленности курсантов; развитие лидерских возможностей; создание конкурентной среды; ознакомление кадетов с разными видами спорта; развитие командного духа и духа; пропаганда активного и здорового образа жизни. Во время обучения кадеты проходят испьтания физической пригодности с помощью фитнес-теста, проводимого два раза в год. Он состоит из бега на 2,4 км в час, максимального числа повторений отжнианий $и$ приседаний, прыжков в длину и бега на скорость.

Ключевые слова: система физической подготовки; офицерские кадры; военные учебные заведения; тенденции профессиональной подготовки; военный колледж; вооруженные силь Канады.

\section{SUMMARY}

Oleksandr Hnydiuk, $\mathrm{PhD}$ in Pedagogy

Bohdan Khmelnytskyi National Academy of the State Border Guard Service of Ukraine

\section{Features of Physical Training for Officers in Military Educational Institutions in Canada}

Introduction. The activities of the State Border Guard Service of Ukraine are taking place in a challenging military-political situation. Under these conditions, the quality and intensity of physical training of border guard officers takes on special significance, since they are required to be hardy, capable of enduring a variety of physical and psychological stresses. In order to find effective ways to solve the problems of physical training of officers of the State Border Guard Service of Ukraine, it is important to study the experience of training military officers in NATO member countries, in particular Canada.

Purpose of this article is to investigate and highlight the features and organizational and pedagogical foundations of officers' physical training in military educational institutions in Canada.

Methods. The methods of analysis, generalization, comparison and systematization were used 
to achieve the goal of the study. The source base is the information contained in the official websites of Canadian military education institutions.

Results. The physical training organization at the Royal Military College of Canada has shown that its educational program offers exceptional opportunities to develop the potential of cadets-athletes. The athletic component is one of the four components of officer training at the Royal Military College of Canada. The physical training program is designed to provide all future officers with the opportunities to participate in physical activities and sports that require exertion in order to develop their general capabilities, self-confidence and leadership. The goal of the program is to improve the physical fitness of cadets; develop leadership capabilities; create a competitive environment; introduce cadets to different sports; develop team spirit; promote an active and healthy lifestyle. During training, cadets are tested on their physical fitness through a fitness test conducted twice a year.

Originality. Scientific novelty lies in the further development of scientific ideas about the organizational and pedagogical foundations of the organization of physical training in educational institutions of NATO countries. The results will contribute to the formation of methodological recommendations to the organizers of physical training to improve its quality. Hence the practical significance of the results of the study.

Conclusion. The quality of physical training in Canada's military colleges is ensured by qualified physical education and sport professionals; high level of physical fitness of applicants for entering military colleges; a significant amount of time in the educational program for physical training and sports; modern sports facilities; a set of measures to create motivation for physical activity and sports. A necessary element of physical training is testing that determine eligibility for further study in military schools and service in the armed forces.

Key words: physical training system; officers; military schools; training trends; military college; Canadian Armed Forces. 